\title{
The role of cabazitaxel in the treatment of metastatic castration-resistant prostate cancer
}

\author{
Che-Kai Tsao, Elena Cutting, Jacob Martin and William K. Oh
}

\begin{abstract}
For decades, cytotoxic therapy was considered ineffective for the treatment of metastatic castration-resistant prostate cancer (mCRPC). Earlier therapies such as estramustine and mitoxantrone received regulatory approval based upon improvement in palliative endpoints. In 2004, docetaxel became the first treatment to demonstrate a significant survival benefit in patients with mCRPC based on two randomized phase III studies, TAX327 and SWOG 99-16. Cabazitaxel, a third-generation taxane, was chosen for clinical development based on its decreased affinity for the drug efflux pump, p-glycoprotein, which is a frequent cause of drug resistance in docetaxel-resistant preclinical models. In 2010, cabazitaxel was approved by the US Food and Drug Administration as the first therapy to show a survival benefit for the treatment of patients with docetaxel-refractory mCRPC. This review summarizes the existing literature on the use of cabazitaxel, focusing on its efficacy and safety in combination with prednisone in the treatment of $\mathrm{MCRPC}$, as well as its role in an era of new therapeutic options.
\end{abstract}

Keywords: cabazitaxel, castration resistant, docetaxel, efficacy, prostate cancer, safety, taxane

\section{Introduction}

Despite advances in screening and treatment, prostate cancer remains a leading cause of cancer death among men, with an expected 29,720 deaths in 2013 [Siegel et al. 2013]. While the use of prostate-specific antigen (PSA) screening increased early disease detection and therapy, a subset of patients inevitably develop metastatic disease, which is considered incurable. Androgendeprivation therapy via surgical orchiectomy or gonadotropin-releasing hormone agonists or antagonists leads to castrate levels of testosterone and is temporarily effective in most patients with advanced prostate cancer. However, eventual progression results in a lethal disease phenotype known as metastatic castration-resistant prostate cancer (mCRPC) [Tsao et al. 2012]. mCRPC was historically thought to be chemotherapy resistant [Scher and Sawyers, 2005], but recent studies have demonstrated that this is not the case.
Taxanes bind microtubules, promoting their stabilization and preventing cellular mitosis and division [Jordan and Wilson, 2004] (Figure 1). Additionally, taxanes inhibit androgen receptor (AR) signaling by binding cellular microtubules and the microtubule-associated motor protein dynein, and consequently preventing AR nuclear translocation [Darshan et al. 2011] (Figure 1). Paclitaxel was the first taxane to receive regulatory approval in the United States as an anticancer therapy. Docetaxel, a second-generation semisynthetic taxane analog with better tolerability and cytotoxicity, was initially approved by the US Food and Drug Administration in 1996 for the treatment of advanced breast cancer. Promising early phase trials led to two phase III studies evaluating its role in the treatment of mCRPC [Picus and Schultz, 1999]. In the TAX 327 study, 1006 patients were randomized to receive prednisone and either docetaxel $\left(30 \mathrm{mg} / \mathrm{m}^{2}\right.$ weekly or $75 \mathrm{mg} / \mathrm{m}^{2}$ every 3 weeks) or
Ther Adv Urol

2014, Vol. 6(3) 97-104

DOI: $10.1177 /$

1756287214528557

(c) The Author(s), 2014.

Reprints and permissions: http://www.sagepub.co.uk/ journalsPermissions.nav
Correspondence to: William K. Oh, MD Icahn School of Medicine at Mount Sinai, The Tisch Cancer Institute, 1 Gustave L Levy Place, New York, NY 10029, USA william.ohamssm.edu

Che-Kai Tsao, MD Elena Cutting Jacob Martin, BA Division of Hematology and Medical Oncology, The Tisch Cancer Institute, Icahn School of Medicine at Mount Sinai, New York, NY, USA 


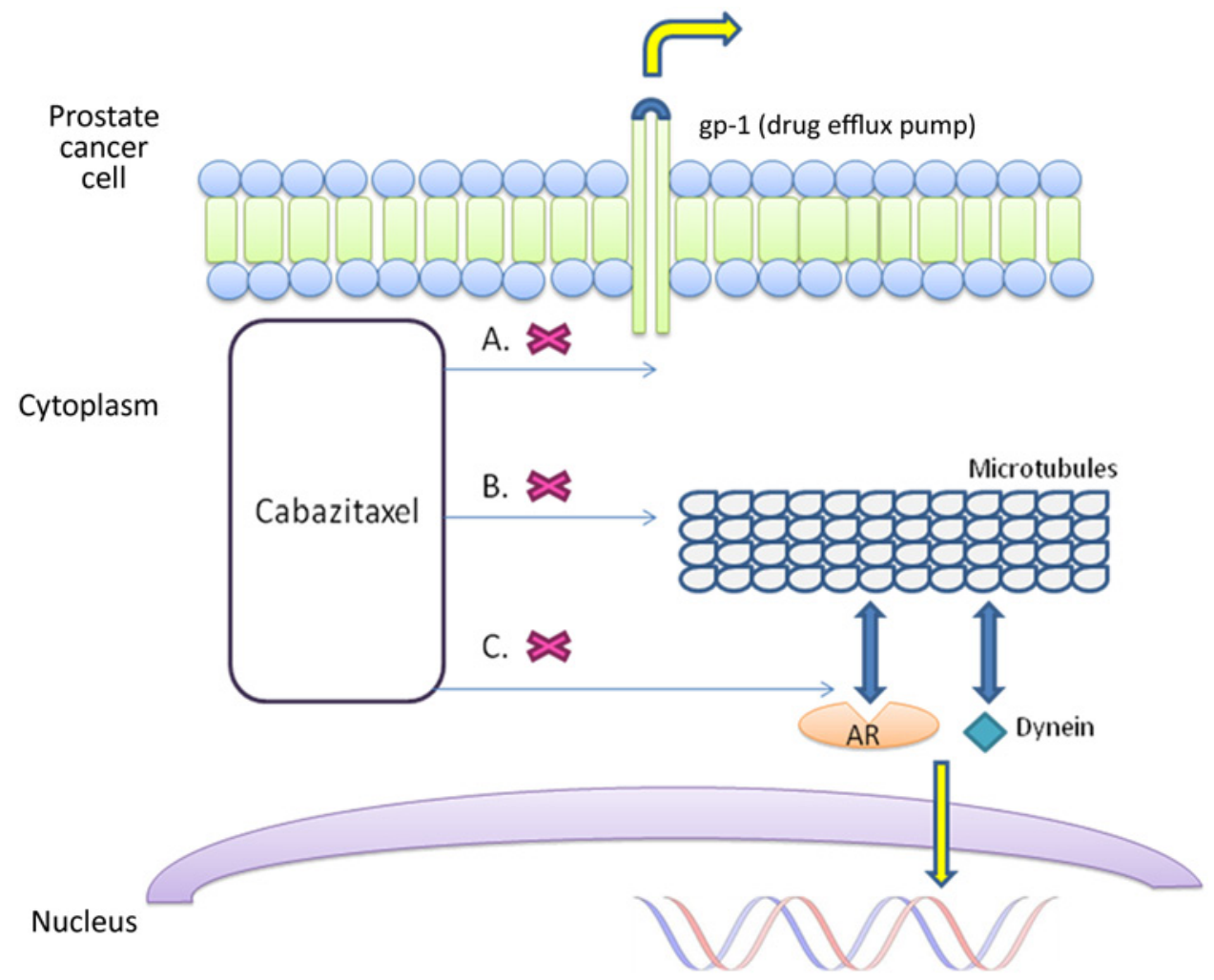

Figure 1. Cabazitaxel: mechanism of action.

A. Lower affinity for the drug efflux pump p-glycoprotein 1 (gp-1). B. Bind cellular microtubules to promote stabilization and prevent cellular mitosis and division. C. Bind cellular microtubules and the microtubule-associated motor protein dynein to inhibit androgen receptor nuclear translocation.

mitoxantrone $12 \mathrm{mg} / \mathrm{m}^{2}$ every 3 weeks. Treatment with docetaxel every 3 weeks was associated with a significant improvement in overall survival compared with mitoxantrone, and additionally led to improvement in other secondary endpoints such as pain and quality of life [Tannock et al. 2004]. In the SWOG 99-16 trial, patients with mCRPC were randomized to receive estramustine and docetaxel versus mitoxantrone and prednisone, and again docetaxel was associated with a significant benefit in overall survival [Petrylak et al. 2004]. However, due to concerns that estramustine/docetaxel coadministration is comparably associated with more significant myelosuppression and gastrointestinal toxicities, docetaxel plus prednisone has become the standard of care for the first-line treatment of progressive $\mathrm{mCRPC}$ in the past decade.

In the past several years, there has been a surge of drug approvals for $\mathrm{mCRPC}$, including sipuleucel$\mathrm{T}$, abiraterone acetate, enzalutamide and radium-223. While these new drugs represent true progress, each treatment has limited activity and unfortunately none of these therapies is curative. Thus effective treatment options after progression on docetaxel remains a significant clinical challenge.

\section{Cabazitaxel: preclinical data}

Preclinical studies of taxane-resistant tumors revealed a high substrate affinity for the adenosine triphosphate dependent drug efflux pump, p-glycoprotein 1 (gp-1). Specifically, upregulation of drug excretion is responsible, at least in part, for inherent and acquired resistance to these agents [Mita et al. 2009]. This observation led to the clinical development of cabazitaxel (Jevtana; Sanofi-Aventis, New Jersey, USA) (XRP6258, RPR 116258A and TXD258), a compound selected specifically for its poor affinity to gp-1.

Cabazitaxel (formula C45H57NO14) is a dimethoxy derivative of docetaxel and is partially synthesized into a single diastereomer from 10-deacetyl baccatin III, the major natural taxane found in the needles of various Taxus species 
[Mita et al. 2012]. In prostate cancer cell lines including DU145, a known castration-resistant prostate cancer cell line, as well as mouse models of prostate cancer, cabazitaxel demonstrated significant antitumor activity. Importantly, cabazitaxel retains significant cytotoxicity in docetaxel-resistant cell lines due to gp-1 overexpression. Another attractive property of cabazitaxel is its enhanced solubility in water-based solutions compared with other taxanes, enabling better blood-brain barrier penetration resulting in higher central nervous system drug concentrations with systemic administration in mouse models.

\section{Early clinical studies}

Two phase I studies evaluated the safety and pharmacokinetic properties of cabazitaxel across various solid tumor types. In the first study between 1999 and 2001, 25 patients (eight with mCRPC) were treated with 102 courses of cabazitaxel, from 10 to $25 \mathrm{mg} / \mathrm{m}^{2}$ intravenously every 3 weeks [Mita et al. 2012]. Although the treatment was generally well tolerated up to $25 \mathrm{mg} / \mathrm{m}^{2}$, grade 4 neutropenia was commonly observed at this dose, and the investigators concluded that a dose of $20 \mathrm{mg} / \mathrm{m}^{2}$ every 3 weeks is appropriate for further clinical testing. Further, of three patients who achieved partial responses to treatment, two had mCRPC, including one who had previously been treated with docetaxel. Another phase I study concluded that the limiting hematologic dose-limiting toxicity was seen at $30 \mathrm{mg} / \mathrm{m}^{2}$ [Diéras et al. 2012]. Two separate phase II studies in women with metastatic breast cancer were reported, further establishing the efficacy and safety of cabazitaxel despite prior disease progression on taxane therapy [Pivot et al. 2008; Villaneuva et al. 2011].

\section{Phase III data: TROPIC study}

A strategic decision was made to proceed directly to a randomized, multicenter phase III study known as TROPIC, without first conducting phase II studies in men with mCRPC. In the TROPIC study, 755 men with mCRPC who previously received docetaxel chemotherapy were randomized to receive either cabazitaxel $25 \mathrm{mg} / \mathrm{m}^{2}$ ( $n$ $=378)$ or mitoxantrone $12 \mathrm{mg} / \mathrm{m}^{2}(n=377)$ every 3 weeks for a maximum of 10 cycles, concurrently with prednisone $10 \mathrm{mg}$ daily [de Bono et al. 2010]. To ensure docetaxel resistance, an interim protocol amendment mandated that study subjects must have received a cumulative dose of docetaxel greater than $225 \mathrm{mg} / \mathrm{m}^{2}$, with only $8 \%(n=59)$ of study subjects failing to meet this requirement. Additionally, half of the patients enrolled had at least one site of soft tissue metastasis, with $25 \%$ having visceral disease, indicating that patients in the study generally had advanced mCRPC.

At the first interim analysis, with a median follow up of 12.7 months, median overall survival was 15.1 months for the cabazitaxel group versus 12.7 months for the mitoxantrone group, corresponding to a $30 \%$ reduction in relative risk of death (hazard ratio $0.70,95 \%$ confidence interval 0.59 $0.83, p<0.0001)$. Other clinical endpoints, including PSA response and progression, objective tumor progression and pain progression all favored the cabazitaxel treatment arm (Table 1). A recent updated analysis 2 years after the originalTROPIC data cutoff (March 2012) confirmed a sustained survival benefit with longer follow up, with cabazitaxel treatment being predictive of survival over 2 years [Bahl et al. 2012].

\section{Pharmacology}

\section{Pharmacokinetics}

In phase I studies, the decline in plasma concentrations after cabazitaxel administration demonstrated triphasic kinetics: first phase with a mean half life $\left(t_{1 / 2}\right)$ of $2.6 \mathrm{~min}$; second phase with a mean $\mathrm{t}_{1 / 2}$ of $1.3 \mathrm{~h}$; and a prolonged third phase with a mean $t_{1 / 2}$ of $77.3 \mathrm{~h}$. Cabazitaxel is equally distributed between blood and plasma [Mita et al. 2009].

\section{Metabolism and drug interaction}

Cabazitaxel is mainly metabolized by the liver [cytochrome P450 (CYP)3A4/5 > CYP2C8], with seven plasma metabolites, and additionally 20 metabolites when excreted. Approximately $80 \%$ of cabazitaxel is excreted within 14 days of administration, primarily in the feces $(76 \%)$. Renal excretion is responsible for $3.7 \%(2.3 \%$ as unchanged drug).

Cabazitaxel is primarily metabolized by CYP3A in vivo and its pharmacokinetics is expected to be affected by both inducers and inhibitors of CYP3A.

\section{Safety profile}

Consistently observed throughout clinical testing of cabazitaxel is a high frequency of hematologic toxicity (Table 2). In the TROPIC study, a total of 
Table 1. Clinical efficacy of therapies approved for docetaxel-resistant prostate cancer.

\begin{tabular}{|c|c|c|c|c|c|}
\hline Treatment & $\begin{array}{l}\text { Overall survival } \\
\text { (months) }\end{array}$ & $\begin{array}{l}\text { Response } \\
\text { rate } \\
(\%)\end{array}$ & $\begin{array}{l}\text { Time to PSA } \\
\text { progression } \\
\text { (months) }\end{array}$ & $\begin{array}{l}\text { Radiographic } \\
\text { progression- } \\
\text { free survival } \\
\text { (months) }\end{array}$ & $\begin{array}{l}\text { Palliative } \\
\text { endpoints }\end{array}$ \\
\hline $\begin{array}{l}\text { Cabazitaxel } \\
\text { + prednisone } \\
\text { versus } \\
\text { mitoxantrone } \\
\text { + prednisone } \\
\text { (TROPIC) }\end{array}$ & 15.1 versus 12.7 & 14.4 versus 4.4 & 6.4 versus 3.1 & 8.8 versus 5.4 & $\begin{array}{l}\text { Similar pain } \\
\text { response rate } \\
(9.2 \% \text { versus } \\
7.7 \%) \\
\text { Two-year follow- } \\
\text { up study shows } \\
\text { an improvement } \\
\text { in daily pain } \\
\text { performance } \\
\text { index }\end{array}$ \\
\hline $\begin{array}{l}\text { Abiraterone } \\
+ \text { prednisone } \\
\text { versus } \\
\text { prednisone } \\
\text { (COU-AA-301) }\end{array}$ & 15.8 versus 11.2 & 14 versus 3 & 8.5 versus 6.6 & 5.6 versus 3.6 & $\begin{array}{l}\text { Improvement in } \\
\text { pain score } \\
\text { ( } 44 \% \text { versus } 27 \% \text { ) } \\
\text { Improvement } \\
\text { in time to } 25 \% \\
\text { having a skeletal } \\
\text { event } \\
\text { (9.9 versus } 4.9 \\
\text { months) }\end{array}$ \\
\hline $\begin{array}{l}\text { Enzalutamide } \\
\text { versus } \\
\text { placebo } \\
\text { (AFFIRM) }\end{array}$ & 18.4 versus 13.6 & 29 versus 4 & 8.3 versus 3.0 & 8.3 versus 2.9 & $\begin{array}{l}\text { Improvement in } \\
\text { FACT-P quality- } \\
\text { of-life response } \\
\text { ( } 43 \% \text { versus } 18 \% \text {, } \\
p<0.001 \text { ) } \\
\text { Improvement } \\
\text { in time to first } \\
\text { skeletal-related } \\
\text { event } \\
\text { (16.7 versus } 13.3 \\
\text { months) }\end{array}$ \\
\hline
\end{tabular}

371 patients received $25 \mathrm{mg} / \mathrm{m}^{2}$ of cabazitaxel every 3 weeks, and neutropenia (94\%), anemia $(97 \%)$ and thrombocytopenia $(47 \%)$ were commonly seen. Specifically, $82 \%$ of the patients experienced grade 3-4 neutropenia, 8\% experienced neutropenic fever, and five patients experienced fatal adverse infectious events. Grade 3-4 anemia $(11 \%)$ and thrombocytopenia (4\%) were far less common (Table 1).

Common nonhematologic toxicities were mainly gastrointestinal in nature: diarrhea (47\%), nausea (34\%), vomiting $(22 \%)$ and constipation $(20 \%)$. Importantly, in this population of patients who previously received docetaxel, significant peripheral neuropathy (grade 3-4) was observed in less than $1 \%$ of patients. Commonly reported adverse effects were fatigue $(37 \%)$, asthenia $(20 \%)$ and hematuria (17\%), with the most commonly reported nonhematologic grade 3-4 adverse events being diarrhea (6\%), fatigue (5\%) and asthenia (5\%). Postmarketing surveillance has led to identification of other previously unreported adverse effects, mainly gastrointestinal and infectious in nature, although given that the sample size is unknown the frequency cannot be accurately quantified.

Whether the safety profile of a drug reported in a phase III clinical trial can translate to 'real world' patients has been evaluated in several expanded access programs. A German compassionate use program with 111 patients reported a comparable treatment efficacy, but with far fewer 'treatmentemergent adverse events' [Heidenreich et al. 2013]. A larger study in older patients also reported a manageable safety profile in practice [Heidenreich et al. 2014]. Factors such as age at least 75 years, treatment cycle 1 and neutrophil count less than $4000 / \mathrm{mm}^{3}$ before cabazitaxel injection were associated with increased risk of developing grade 3 or higher neutropenia and 
Table 2. Common adverse effects of cabazitaxel.

\begin{tabular}{lrrr}
\hline Adverse event & All events & Grade $\geq 3$ & Special considerations \\
\hline Hematologic & & & \\
Neutropenia & $347(94 \%)$ & $303(82 \%)$ & More common age $\geq 65$; consider G-CSF prophylaxis \\
Leukopenia & $355(96 \%)$ & $253(68 \%)$ & \\
Anemia & $361(97 \%)$ & $39(11 \%)$ & \\
Thrombocytopenia & $176(47 \%)$ & $15(4 \%)$ & \\
Nonhematologic & & & \\
Diarrhea & $173(47 \%)$ & $23(6 \%)$ \\
Fatigue & $136(37 \%)$ & $18(5 \%)$ \\
Back pain & $60(16 \%)$ & $14(4 \%)$ \\
Nausea & $127(34 \%)$ & $7(2 \%)$ \\
Vomiting & $84(23 \%)$ & $7(2 \%)$ \\
Hematuria & $62(17 \%)$ & $7(2 \%)$ \\
Abdominal pain & $43(12 \%)$ & $7(2 \%)$ \\
Dyspnea & $44(12 \%)$ & $5(1 \%)$ \\
Constipation & $76(20 \%)$ & $4(1 \%)$ \\
Pyrexia & $45(12 \%)$ & $4(1 \%)$ \\
Arthralgia & $39(11 \%)$ & $4(1 \%)$ \\
Postmarket reporting (frequency not determined) \\
Colitis, enterocolitis, gastritis, neutropenic enterocolitis, gastrointestinal hemorrhage and perforation, $\geq 75$ and prior radiotherapy \\
ileus and intestinal obstruction
\end{tabular}

neutropenic complications. In fact, prophylactic use of granulocyte colony-stimulating factor (G-CSF) significantly reduced this risk by $30 \%$ in each cycle of therapy (odds ratio $0.70, p=0.04$ ). These results have led to the hypothesis that aggressive counseling and prophylactic G-CSF use may be effective in reducing adverse events.

\section{Special patient populations}

\section{Geriatric use}

Although population pharmacokinetic analysis did not demonstrate significant differences in geriatric patients (age > 65), these older patients were more likely to experience adverse reactions, including neutropenia, fatigue, asthenia, pyrexia, dizziness, urinary tract infection and dehydration. Close monitoring, routine use of prophylactic G-CSF, and aggressive and early therapy for signs of infection should be strongly considered in this population.

\section{Organ impairment}

Despite lack of clinical trial enrollment of patients with liver function impairment, cabazitaxel is metabolized mainly by the liver and is not recommended for use if total bilirubin or transaminases are above 1.5 times the upper normal limit. Conversely, although there are no specific guidelines, therapy in patients with renal impairment could be considered with close monitoring.

\section{Optimal timing and dose of cabazitaxel}

Even after the regulatory approval of cabazitaxel in the treatment of docetaxel-refractory mCRPC, many questions remain with regard to its optimal use, leading to further clinical testing to answer these important questions (Table 3). One question is the optimal dose and frequency of cabazitaxel administration in men with mCRPC. Given concerns of significant myelosuppression with administration of cabazitaxel at $25 \mathrm{mg} / \mathrm{m}^{2}$, an ongoing randomized phase III study will evaluate the safety and efficacy of cabazitaxel at $20 \mathrm{mg} / \mathrm{m}^{2}$. In addition, alternative schedules of cabazitaxel administration are being evaluated. The role of supportive care measures such as prophylactic G-CSF and antibiotics to minimize complications associated with myelosuppression are also the subject of ongoing studies. In fact, many 
Table 3. Ongoing clinical trials of cabazitaxel.

\begin{tabular}{|c|c|c|c|c|}
\hline $\begin{array}{l}\text { ClinicalTrials.gov } \\
\text { identifier }\end{array}$ & Trial summary & $\begin{array}{l}\text { Study } \\
\text { phase/ } \\
\text { enrollment }\end{array}$ & Primary endpoint & $\begin{array}{l}\text { Target completion } \\
\text { date }\end{array}$ \\
\hline \multicolumn{5}{|l|}{ Dose and frequency } \\
\hline NCT01518283 & $\begin{array}{l}4 \text { weekly cabazitaxel } \\
10 \mathrm{mg} / \mathrm{m}^{2} \text { of } 5 \text {-week cycle }\end{array}$ & II $(n=74)$ & PSA progression & September 2014 \\
\hline NCT01558219 & $\begin{array}{l}\text { Cabazitaxel } 16 \mathrm{mg} / \mathrm{m}^{2} \\
\text { every } 2 \text { weeks }\end{array}$ & II $(n=60)$ & $\begin{array}{l}\text { Safety and } \\
\text { tolerability }\end{array}$ & December 2014 \\
\hline NCT01541007 & $\begin{array}{l}5 \text { weekly cabazitaxel } \\
10 \mathrm{mg} / \mathrm{m}^{2} \text { of } 6 \text {-week cycle }\end{array}$ & II $(n=100)$ & Cumulative dose & June 2015 \\
\hline NCT01308580 & $\begin{array}{l}\text { Compare } 20 \mathrm{mg} / \mathrm{m}^{2} \text { with } \\
25 \mathrm{mg} / \mathrm{m}^{2}\end{array}$ & III $(n=1200)$ & Overall survival & September 2017 \\
\hline \multicolumn{5}{|c|}{ Combination therapy (with cabazitaxel) } \\
\hline NCT01845792 & Abiraterone/prednisone & $1 / I I(n=72)$ & PSA reduction & July 2019 \\
\hline NCT01505868 & Carboplatin & $I / I I(n=178)$ & $\begin{array}{l}\text { Progression-free } \\
\text { survival }\end{array}$ & July 2029 \\
\hline NCT01578655 & Custirsen & III $(n=630)$ & Overall survival & December 2015 \\
\hline NCT01083615 & Custirsen & III (n= 292) & Pain palliation & December 2013 \\
\hline NCT01650285 & Cabazitaxel with radiation & II $(n=24)$ & $\begin{array}{l}\text { Maximum } \\
\text { tolerated dose }\end{array}$ & January 2016 \\
\hline NCT01952223 & Cabazitaxel with radiation & III $(n=1048)$ & $\begin{array}{l}\text { Progression-free } \\
\text { survival }\end{array}$ & September 2026 \\
\hline \multicolumn{5}{|l|}{ Other disease states } \\
\hline NCT01576029 & $\begin{array}{l}\text { Early switch to } \\
\text { cabazitaxel }\end{array}$ & II $(n=78)$ & PSA progression & November 2014 \\
\hline NCT01718353 & $\begin{array}{l}\text { Early switch from } \\
\text { docetaxel to cabazitaxel } \\
\text { and opposite sequence }\end{array}$ & II $(n=100)$ & $\begin{array}{l}\text { PSA and } \\
\text { circulating tumor } \\
\text { cells }\end{array}$ & July 2015 \\
\hline NCT01941550 & Neoadjuvant cabazitaxel & II $(n=35)$ & $\begin{array}{l}\text { Progression free } \\
\text { survival }\end{array}$ & August 2018 \\
\hline NCT01308567 & $\begin{array}{l}\text { Cabazitaxel versus } \\
\text { docetaxel }\end{array}$ & III $(n=1170)$ & Overall survival & December 2017 \\
\hline NCT01978873 & $\begin{array}{l}\text { Early chemotherapy with } \\
\text { curative intent }\end{array}$ & III $(n=400)$ & Overall survival & November 2019 \\
\hline \multicolumn{5}{|l|}{ Supportive care } \\
\hline NCT01649635 & $\begin{array}{l}\text { G-CSF and antibiotic } \\
\text { prophylaxis }\end{array}$ & II (n= 45) & $\begin{array}{l}\text { Rate of } \geq 3 \\
\text { neutropenia }\end{array}$ & July 2015 \\
\hline
\end{tabular}

practitioners consider prophylactic G-CSF a standard of care in patients with $\mathrm{MCRPC}$ receiving cabazitaxel, given this population tend to be older and are at high risk of developing neutropenia and infectious complications.

Another important question is the effectiveness and tolerability of cabazitaxel combined with other therapies. Ongoing phase I/II trials are evaluating the combination of cabazitaxel with both approved therapies (e.g. carboplatin, abiraterone, mitoxantrone) and investigational agents (e.g. tasquinomid, custirsen).
An additional and critical question is whether cabazitaxel use should be limited to treatment of docetaxel-refractory mCRPC. If cabazitaxel is more potent than docetaxel, then perhaps it should be considered a first-line cytotoxic agent in mCRPC. An ongoing phase III study is randomizing patients with $\mathrm{mCRPC}$ to receive either docetaxel $75 \mathrm{mg} / \mathrm{m}^{2}$ or cabazitaxel $25 \mathrm{mg} / \mathrm{m}^{2}$ as first-line cytotoxic therapy (FIRSTANA). Intriguingly, a recent press release by the National Cancer Institute reported that, in the phase III CHAARTED clinical trial, docetaxel in combination with androgen deprivation therapy in 
hormone-sensitive metastatic prostate cancer was associated with a survival benefit compared with Androgen deprivation therapy (ADT) alone. This leads to speculation as to whether cabazitaxel, a more potent taxane than docetaxel, may ultimately serve to produce even better results in patients with metastatic hormone-sensitive disease.

In terms of sequencing cabazitaxel in relation to abiraterone acetate, enzalutamide or radium-223, which have each been approved for therapy after docetaxel treatment, there are no prospective data that can guide the clinician about how best to do so. Each of these therapies was studied without respect to the availability of the others. Despite emerging retrospective data to answer these questions, these attempts are speculative in nature, and we can only use clinical judgment in the short term to decide whether a patient whose condition has progressed on docetaxel should switch classes of drugs to an androgen-pathway agent or a bone-targeted therapy versus staying on cytotoxic chemotherapy.

\section{Conclusion}

The clinical development of cabazitaxel has provided an important proof of principle that targeted therapy to overcome a specifically identified mechanism of resistance in the treatment of mCRPC is possible. In this case, a novel taxane was demonstrated to have clinical activity in docetaxel-resistant mCRPC. Given that mCRPC remains incurable, even with the advent of multiple new therapies, each approved drug will have a place in both extending survival and improving patient quality of life. Cabazitaxel represents a therapeutic option for men with metastatic CRPC whose condition has progressed on docetaxel and is associated with a survival advantage.

\section{Funding}

This research received no specific grant from any funding agency in the public, commercial, or notfor-profit sectors.

\section{Conflict of interest statement}

Dr. William K. Oh serves on the advisory board for Sanofi-Aventis.

\section{References}

Bahl, A., Oudard, S., Tombal, B., Ozgüroglu, M., Hansen, S., Kocak, I. et al. (2012) Impact of cabazitaxel on 2-year survival and palliation of tumour-related pain in men with metastatic castration-resistant prostate cancer treated in the TROPIC trial. Ann Oncol 24: 2402.

Darshan, M., Loftus, M., Thadani-Mulero, M., Levy, B., Escuin, D., Zhou, X. et al. (2011) Taxane-induced blockade to nuclear accumulation of the androgen receptor predicts clinical responses in metastatic prostate cancer. Cancer Res 71: 6019.

de Bono, J., Oudard, S., Ozguroglu, M., Hansen, S., Machiels, J., Kocak, I. et al. (2010) Prednisone plus cabazitaxel or mitoxantrone for metastatic castrationresistant prostate cancer progressing after docetaxel treatment: a randomised open-label trial. The Lancet 376: 1147.

Diéras, V., Lortholary, A., Laurence, V., Delva, R., Girre, V., Livartowski, A. et al. (2013) Cabazitaxel in patients with advanced solid tumours: results of a phase I and pharmacokinetic study. Eur $\mathcal{F}$ Cancer 49: 25-34.

Heidenreich, A., Bracarda, S., Mason, M., Ozen, H., Sengelov, L., Van Oort, I. et al. (2014) Safety of cabazitaxel in senior adults with metastatic castrationresistant prostate cancer: results of the European compassionate-use programme. Eur $\mathcal{F}$ Cancer 31 January (epub ahead of print).

Heidenreich, A, Scholz, H., Rogenhofer, S., Arsov, C., Retz, M., Müller, S. et al. (2013) Cabazitaxel plus prednisone for metastatic castration-resistant prostate cancer progressing after docetaxel: results from the German compassionate-use programme. Eur Urol 63: 977.

Jordan, M. and Wilson, L. (2004) Microtubules as a target for anticancer drugs. Nat Rev Cancer 4: 253.

Mita, A., Denis, L., Rowinsky, E., Debono, J., Goetz, A., Ochoa, L. et al. (2009) Phase I and pharmacokinetic study of XRP6258 (RPR 116258A), a novel taxane, administered as a 1 -hour infusion every 3 weeks in patients with advanced solid tumors. Clin Cancer Res 15: 723.

Mita, A., Figlin, R. and Mita, M. (2012) Cabazitaxel: more than a new taxane for metastatic castrateresistant prostate cancer? Clinical Cancer Res 18, 6574.

Petrylak, D., Tangen, C., Hussain, M., Lara, P. Jr, Jones, J., Taplin, M. et al. (2004) Docetaxel and estramustine compared with mitoxantrone and prednisone for advanced refractory prostate cancer. $N$ Engl f Med 351: 1513.

Picus, J. and Schultz, M. (1999) Docetaxel (Taxotere) as monotherapy in the treatment of hormonerefractory prostate cancer: preliminary results. Semin Oncol 26: 14.

Pivot, X., Koralewski, P., Hidalgo, J., Chan, A., Gonçalves, A., Schwartsmann, G. et al. (2008) A multicenter phase II study of XRP6258 administered 
Visit SAGE journals online http://tau.sagepub.com

(S) SAGE journals as a 1-h i.v. infusion every 3 weeks in taxane-resistant metastatic breast cancer patients. Ann Oncol 9: 1547-1552.

Scher, H. and Sawyers, C. (2005) Biology of progressive, castration-resistant prostate cancer: directed therapies targeting the androgen-receptor signaling axis. $f$ Clin Oncol 23: 8253.

Siegel, R., Naishadham, D. and Jemal, A. (2013). Cancer statistics. CA Cancer $\mathcal{F}$ Clin 63: 11.

Tannock, I., de Wit, R., Berry, W., Horti, J., Pluzanska, A., Chi, K. et al. (2004) Docetaxel plus prednisone or mitoxantrone plus prednisone for advanced prostate cancer. N Engl F Med 351: 1502.

Tsao, C., Galsky, M., Small, A., Yee, T. and Oh, W. (2012) Targeting the androgen receptor signalling axis in castration-resistant prostate cancer. BfU Int 110: 1580.

Villanueva, C., Awada, A., Campone, M., Machiels, J., Besse, T., Magherini, E. et al. (2011) A multicentre dose-escalating study of cabazitaxel (XRP6258) in combination with capecitabine in patients with metastatic breast cancer progressing after anthracycline and taxane treatment: a phase I/II study. Eur F Cancer 47: 1037. 